\title{
Statistical modelling of the main features of the Artemisia pollen season in Wroclaw, Poland, during the 2002-2011 time period
}

\author{
Anetta Drzeniecka-Osiadacz • Justyna Krynicka • \\ Malgorzata Malkiewicz • Kamilla Klaczak • \\ Krzysztof Migala
}

Received: 13 August 2013 / Accepted: 26 January 2014 / Published online: 1 March 2014

(C) The Author(s) 2014. This article is published with open access at Springerlink.com

\begin{abstract}
The aim of this article is to present statistical forecasting models concerning the dynamics of Artemisia pollen seasons in Wrocław, including the start and end, the date of maximum pollen concentration and seasonal pollen index (SPI). For statistical evaluation, use was made of aerobiological and meteorological data from the last 10 years (2002-2011). Based on this data, agroclimatic indicators, i.e. crop heat units (CHUs), were determined for various averaging periods. The beginning of the Artemisia pollen season in the studied time period, on average, took place on 23 June. Its length usually varied between 26 and 45 days, and maximum daily concentrations occurred between 31 July and 18 August. It was found that the beginning of the pollen season depends, above all, on the values of CHUs and photothermal unit (PTU) $(p<0.05)$ in the period from March to June, for various thermal thresholds. The date of maximum daily concentration correlates with sunshine duration, PTU and air temperature for June and July $(p<0.05)$. On the other hand, SPI is connected with thermal variables, i.e. average, maximum and minimum air temperatures and CHUs and heliothermal unit (HTU) for July $(p<0.05)$ and the beginning of spring. Based on the correlation analysis and the chosen variables, regression models for the beginning date of Artemisia pollen season and SPI were prepared, which were then verified by using leave-one-out cross-validation. A better fit between modelled and actual values was found for the analysis concerning the season start date than for the SPI.
\end{abstract}

A. Drzeniecka-Osiadacz $\cdot$ J. Krynicka $(\bowtie) \cdot K$. Migała Department of Climatology and Atmosphere Protection, Institute of Geography and Regional Development, University of Wrocław, 8 Aleksandra Kosiby Street, 51-621 Wrocław, Poland

e-mail: justyna.krynicka@uni.wroc.pl

M. Malkiewicz $\cdot$ K. Klaczak

Department of Paleobotany, Institute of Geological Sciences, University of Wrocław, 34 Cybulskiego Street, 50-205 Wrocław, Poland

\section{Introduction}

The Artemisia L. pollen is one of the three major aeroallergens in Central and Eastern Europe and is the main cause of summertime respiratory illnesses and conjunctivitis (D'Amato et al. 1998). Of the 57 species of Artemisia L. occurring in Europe, three (Artemisia. vulgaris L., Artemisia campestris L. and Artemisia absynthium L.) are common anemophilous plants (Tutin et al. 1980) that are connected with human habitation. They preferably grow on ruderal and disturbed soils, in urban and suburban areas, at industrial and building sites, in rural areas or countryside, around farms and along roads. They are less abundant in biologically undisturbed and stable environments (Spieksma and von Wahl 1991).

Vegetative growth of $A$. vulgaris occurs from early spring to late autumn. The germination of Artemisia seeds is influenced by temperature. They germinate over a wide range of temperature from 5 to $30^{\circ} \mathrm{C}$, preferably between 10 and $20^{\circ} \mathrm{C}$. Maximum growth takes place in the summer months. The first flowers appear on the plant after 4 months from the start of growth and mature in late summer into early autumn. The required photoperiod for flowering was found to be 4 $16 \mathrm{~h}$ for 4 weeks (Henderson and Weller 1985; Barney and DiTommaso 2003).

More than $15 \%$ of the average population suffers from allergies (Ipsen et al. 1985; D'Amato et al. 1998). This value is twice as high in urban populations (Sydbom et al. 2001). An increased sensitivity of respiratory tracts to environmental factors, including inhaled allergens (Kinney et al. 2000; de la Guardia et al. 2006; Tombácz et al. 2007; Komorowski 2012), is correlated with the high air pollution found in urban areas (Sydbom et al. 2001). Epidemiological studies show that respiratory diseases (including asthma) occur in $28 \%$ of the population of Wrocław (Komorowski 2012). Therefore, pollinosis is an important factor in the quality of life of an urban population (Bonofiglio et al. 2013). 
Attempts to create a forecasting model that would predict pollen concentrations and characterize the pattern of pollen season have already been undertaken for a long time (Koivikko et al. 1986; Wolf et al. 1998; Stach et al. 2007; Galán et al. 2008; Orlandi et al. 2010; Grewling et al. 2012). Mathematical models include different meteorological data, i.e. wind speed and direction, air humidity, sunshine duration, structure of the atmospheric boundary layer as well as the impact of terrain conditions and long-range transport (Giner et al. 1999; Puc 2006; Laursen et al. 2007). Recently, attention has been brought onto the dependency between the type of air circulation and the type of Artemisia pollen season and also the influence of agroclimatic factors (crop heat units (CHUs)) on the beginning of the pollen season (Malkiewicz et al. 2013).

It is therefore necessary to create a meteorological model for the vegetation period, which would be used as a forecasting tool for people with pollinosis. The following analysis is an example of such a model.

\section{Data and methods}

\subsection{Study area}

The pollen data and meteorological variables were gathered in Wrocław during the 2002-2011 time period. Wrocław $\left(51^{\circ} 07^{\prime}\right.$ $\mathrm{N}, 17^{\circ} 02^{\prime} \mathrm{E}$ ) is located in south-western Poland (Fig. 1), covering an area of $293 \mathrm{~km}^{2}$. Wrocław has a population of about 650,000 inhabitants.

Green areas like parks, forest, grasslands, wastelands and agricultural areas represent the largest share $(60 \%)$ within the spatial structure of Wrocław. Industrial (13\%) and built-up areas $(17 \%)$ tend to use the second largest part of landscape. In addition, there are many watercourses, with the largest one being the Odra River. Because of such a varied mosaic of land use, good conditions exist in Wrocław for colonization by many different types of plants, which include ruderal species.

Due to its location in the mid-latitudes, this city is characterized by the typical features of a transitory temperate climate zone. The predominance of oceanic influences and westerly atmospheric circulation is quite evident in this area (Dubicka 1994). Its location in the foreground of the Sudetes causes this region to be thermally privileged. The mean annual temperature during the $1971-2000$ time period was $8.8^{\circ} \mathrm{C}$ and shows an increasing tendency (the mean annual temperature in the 2000-2009 time period is $9.6^{\circ} \mathrm{C}$ ). The coolest month is January (the mean air temperature is $-0.6^{\circ} \mathrm{C}$ ) while the hottest is July $\left(18.3^{\circ} \mathrm{C}\right)$. Yearly precipitation amounts to $575.5 \mathrm{~mm}$, with the maximum occurring in July $(83.2 \mathrm{~mm}$ ) (Środowisko Wrocławia. Informator 2010). Due to these favourable thermal conditions, the vegetation period in Wrocław is among the longest in Poland, as on average, it lasts 234 days (Dubicka 1996).

\subsection{Pollen data}

In Wrocław, the pollen concentrations of Artemisia L. have been measured with the help of a Burkard-type high-volume pollen trap (Hirst 1952) since 2002. The sampler was located near the city centre, $20 \mathrm{~m}$ above ground level on the roof of the Institute of Geology of the University of Wrocław.

Airborne pollen counts were analyzed following the recommendations of the International Association for Aerobiology (Mandrioli et al. 1998). The cylinder with tape was replaced at 9.00 a.m. each Thursday. Pollen grains were counted under a light microscope along four longitudinal transects and expressed as a number of pollen grains per cubic metre of air $\left(\mathrm{p} \mathrm{m}^{-3}\right)$. The main pollen season criterion was analyzed according to Andersen (1991) and Emberlin et al. (1993), i.e. $95 \%$ of the annual total pollen concentration (95\% method) was taken into account (eliminating the initial $2.5 \%$ and final $2.5 \%$ ).

\subsection{Meteorological data}

The meteorological data were gathered at a monitoring station of the Department of Climatology and Atmosphere Protection of the University of Wrocław, about $5 \mathrm{~km}$ west of the pollen sampling site. An automatic weather station provided the main meteorological data: temperature, wind speed and direction and relative humidity. Moreover, these data were augmented by standard measurements of sunshine duration and sum of precipitation.

\subsection{Data processing}

The data basis consisted of daily Artemisia pollen concentrations and daily averages or sums of meteorological variables.

To describe the pollen season dynamics in the studied decade, individual season phases were calculated for which the cumulative pollen sum amounted to 1.0-2.5, 2.5-25.0, $25.0-50.0,50.0,50.0-75.0,75.0-97.5$ and $97.5-99.0 \%$ of the total annual amount (Latałowa et al. 2002).

The meteorological variables were considered generally for the vegetation period. Starting from the beginning of the vegetation period, the meteorological conditions influence plant growth and determine pollen production.

The start and end dates of the vegetation season for each year were determined based on average daily temperatures, as were the sums of active temperatures (Szyga-Pluta 2011; Żmudzka 2012). While determining the vegetation period, the methods of Huculak and Makowiec (1977) and Samborski and Bednarczuk (2009) were used. While evaluating the production potential of plants, it may be helpful to make use of agroclimatic indices, which, up to now, have been used mainly to evaluate plant production in agriculture (Brown and Bootsma 1993); yet now, there are attempts to forecast pollen 


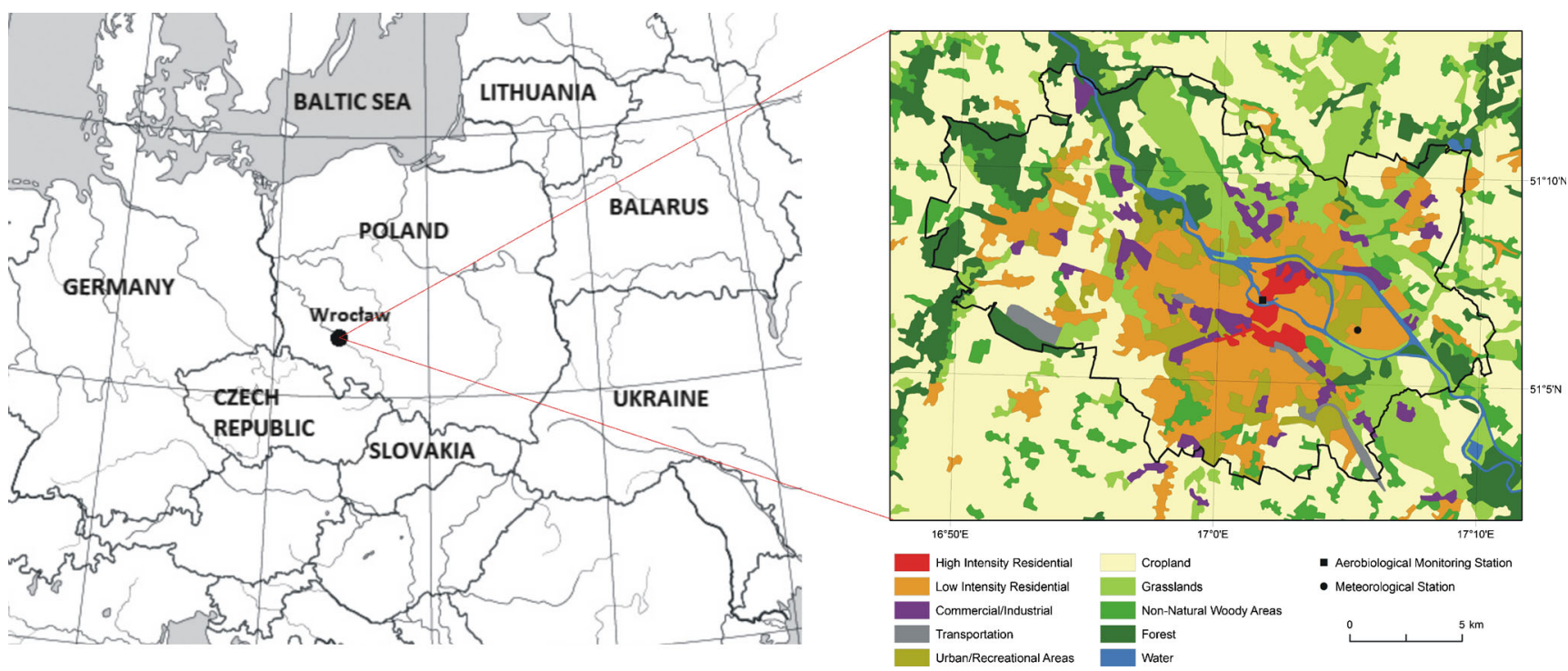

Fig. 1 The location of the measurement stations and land use map of Wrocław

seasons with the help of these indicators (Orlandi et al. 2010). Among the most commonly used agroclimatic indicators are the effective sums of air temperature above the thresholds of 5 , 10 and $15{ }^{\circ} \mathrm{C}$, which give information about plant thermal resources (Dubicka and Głowicki 2000; Żmudzka 2012), CHUs, growing degree days (GDDs), the hydrothermal index (HTI) and the photothermal unit (PTU) (García-Mozo et al. 2002; Thavaprakaash et al. 2007; OMAFRA 2009; Malkiewicz et al. 2013).

In order to evaluate the influence of meteorological factors on the course of the pollen season, use was made of values that characterize the energy and water potentials, such as the CHUs index, HTI, the heliothermal unit (HTU), the PTU index, average monthly and decade temperatures, and the total precipitation and number of days with precipitation of various intensities, in addition to the water vapour pressure $e(\mathrm{hPa})$ and the vapour pressure deficit $d(\mathrm{hPa})$.

In order to calculate the CHUs index, the values for the maximum and minimal temperatures were used, and in calculating GDDs, the base temperature was assumed to be $5{ }^{\circ} \mathrm{C}$.

The following Eqs. (1-6) were used to calculate agroclimatological indices for a given site:

Daily CHUs

$$
\mathrm{CHUs}=\frac{Y_{\max }+Y_{\min }}{2}
$$

where

$Y_{\max }=3.33\left(T_{\max }-10\right)-0.084\left(T_{\max }-10\right)^{2}$

$Y_{\min }=1.8\left(T_{\min }-4.4\right)$ where $T_{\max }$ is the daily maximum air temperature $\left({ }^{\circ} \mathrm{C}\right)$ (measured from midnight to midnight) and $T_{\min }$ is the daily minimum temperature $\left({ }^{\circ} \mathrm{C}\right)$; if the value of $Y_{\max }$ or $Y_{\min }$ is negative, 0 should be set.

Hydrothermal index (HTI)

Selyaninov's HTI (Selyaninov 1937) was calculated as the following:

$$
\mathrm{HTI}=\frac{R}{0.1 \cdot \sum T_{>10^{\circ} \mathrm{C}}}
$$

where $R$ is the sum of precipitation for a given period and $T$ is the temperature above threshold value $10{ }^{\circ} \mathrm{C}$.

Heliothermal unit (HTU)

$$
\mathrm{HTU}=\sum_{i=1}^{n} \mathrm{CHUs} \cdot \mathrm{SD}
$$

where CHUs is the crop heat units (instead of GDDs) and SD is the sunshine duration $(\mathrm{h})$.

Photothermal unit (PTU)

$$
\mathrm{PTU}=\sum_{i=1}^{n} \mathrm{CHUs} \cdot N
$$

where CHUs is the crop heat units (instead of GDDs) and $N$ is the length of day (h).

The data were subjected to Pearson's correlation test in order to chart the relationship between meteorological parameters and seasonal pollen characteristics of Artemisia $\mathrm{L}$. The beginning of the pollen season, the maximum daily concentration date, the pollen season end date and the seasonal pollen index (SPI) were taken into account. Based on this correlation analysis, regression equations were constructed for 10 years for the two main 
parameters, i.e. the pollen season start date and the SPI. In order to evaluate the significance of independent variables, a crossvalidation procedure was conducted (Gidskehaug et al. 2008). The calculated results were compared with the measured ones using statistical methods such as a systematic deviation from the true value (BIAS), normalized mean square error (NMSE), root-mean-square error (RMSE), fractional bias (FB), the fractions of factor of two (FA2), mean error (ME) and mean percentage error (MPE) (Bellocchi et al. 2010).

\section{Results and discussion}

\subsection{Pollen season characteristics}

From the studies conducted in Wrocław, it is observed that Artemisia L. pollen seasons can generally be described as compact of average length and with clear maximum concentration peaks. The mean start date of the Artemisia pollen season in Wrocław calculated for the 2002-2011 period is 23 July. The year-to-year variation in start date is rather small, with a difference of 11 days between the earliest (2002) and the latest date (2010). However, it appears that the most typical start of the Artemisia pollen season in this period took place at around the 24th-27th of July (Table 1).

The Artemisia pollen season beginning, determined by using the $98 \%$ method, occurs about 7-9 days earlier than according to the criteria assumed in this paper. However, there were years (2002 and 2005) in which this pollen season began 20 days earlier (Table 1). Moreover, the beginning of pollen detection was, on average, more than 20 days earlier than the season start date, but this could be attributed to a long-range transport of pollen grains. For the selected days, a backwards trajectory simulation was employed, starting on the day of peak values and going backwards in time 2 or 3 days depending on air conditions (pressure systems and their movement).

Selected episodes (Fig. 2) indicated that the source area of the Artemisia pollen at the beginning of the pollen season could be located to the north, north-west and west of the measurement site. The data gathered at the few aerobiological monitoring stations in Europe indicated that the earliest start date of Artemisia pollen season occurred in Belgium (Grewling et al. 2012).

The length of the Artemisia pollen season varied from 2628 days (in 2007 and 2009) to 44-45 days (in 2002 and 2010) and even 62 days in the atypical year 2006. The season tended to be shorter in the years of high annual sums (Table 1). Myszkowska et al. (2011), based on long-term studies in Kraków (1991-2008), consider the pollen seasons of Artemisia there to be short (27-30 days), while in other cities of Poland, Artemisia pollen seasons are much longer (40-45 and even 54 days) (Weryszko-Chmielewska and Piotrowska
2004; Puc 2006; Stach et al. 2007) and are comparable with the results obtained for Wrocław.

Artemisia pollen is commonly observed from the last week of July to the last week of August in north-west Europe (Spieksma et al. 1980; Nilsson and Palmberg-Gotthard 1982; Goldberg et al. 1988; Puc 2006; Stach et al. 2007; Myszkowska et al. 2011). In the southern parts of Europe, Artemisia pollen is observed from the first week of August to the first week of September (Spieksma and von Wahl 1991). In the studied decade, the maximum daily concentrations occurred between 6 and 18 August. The maximum daily values also differed from year to year. In the years 2006 and 2010, they were below the value of 60 grains $\mathrm{p} \mathrm{m}^{-3}$ of air, while in 2008, they were almost four times higher (223 grains $\mathrm{p} \mathrm{m}^{-3}$ of air).

In order to determine the dynamics of Artemisia pollen seasons, seven consecutive stages were designated, determined by the $1.0,2.5,25.0,50.0,75.0,97.5$ and 99.0 percentiles of the annual total pollen count (Fig. 3).

The Artemisia pollen seasons in the studied years are characterized by relatively long A and B stages, where the pollen count reaches 2.5 and $25.0 \%$ of the annual total pollen count. In total, both of these stages lasted between 19 and 24 days in the majority of the studied years, and in 2002 and 2005 , they lasted a maximum of 34-35 days. The F stage ( $97.5 \%$ of the annual sum) is similarly elongated. It usually lasts from 12 to 18 days; only in the years 2007-2009 that it lasted only 6-9 days. An exceptionally long F stage was found in the years 2006 and 2010, when $97.5 \%$ of the annual sum was attained only after 27 and 35 days. 99\% of the annual sum (G stage) was attained very quickly in the majority of the studied years, after about 5-6 days, and exceptionally even after 1 (the year 2009) or 2 (the year 2006) days (Fig. 3). 50\% of the annual sum is attained after 4-5 days of the $\mathrm{C}$ stage. Exceptional cases were recorded in the year 2009, when $50 \%$ of the annual sum was attained after 3 days of the $C$ stage, while in 2002 and 2006, it was attained only after 6 days. The E stage is also short, and it usually lasts 4 days. Exceptional cases were noted in the year 2008 , when $75.0 \%$ of the annual pollen sum was attained after 2 days of this stage (Fig. 3).

The maximum daily pollen concentrations usually take place relatively late in the pollen season. In half of the studied years, they were recorded only 2-4 days after the phase that composes $50.0 \%$ of the annual pollen sum. In two years (2010 and 2011), the maximum daily concentration coincided with the time of attaining $50.0 \%$ of the annual sum.

\subsection{Meteorological condition characteristic}

The fundamental factors that influence plant development are the energy and water resources of the environment. Due to this, the analysis of pollen seasons should be augmented by a characterization of the vegetation season that precedes the 
Table 1 Basic characteristic of pollen season during the 2002-2011 time period

\begin{tabular}{|c|c|c|c|c|c|c|c|}
\hline Year & $\begin{array}{l}\text { Start date } \\
(95 \%)\end{array}$ & $\begin{array}{l}\text { Start date } \\
(98 \%)\end{array}$ & $\begin{array}{l}\text { Maximum concentration } \\
\left(\mathrm{p} \mathrm{m}^{-3}\right)\end{array}$ & $\begin{array}{l}\text { Date of maximum } \\
\text { concentration }\end{array}$ & $\begin{array}{l}\text { End date } \\
(95 \%)\end{array}$ & $\begin{array}{l}\text { Length of pollen } \\
\text { season }(95 \%)\end{array}$ & SPI \\
\hline 2002 & 17.07 & 27.06 & 105 & 31 July & 29 August & 44 & 1,192 \\
\hline 2003 & 18.07 & 9.07 & 117 & 9 August & 28 August & 42 & 1,523 \\
\hline 2004 & 24.07 & 14.07 & 167 & 6 August & 24 August & 32 & 2,123 \\
\hline 2005 & 25.07 & 5.07 & 107 & 14 August & 2 September & 40 & 1,341 \\
\hline 2006 & 24.07 & 17.07 & 58 & 18 August & 23 September & 62 & 664 \\
\hline 2007 & 25.07 & 21.07 & 178 & 15 August & 21 August & 28 & 1,668 \\
\hline 2008 & 26.07 & 19.07 & 223 & 11 August & 21 August & 27 & 1,507 \\
\hline 2009 & 27.07 & 20.07 & 122 & 7 August & 21 August & 26 & 1,298 \\
\hline 2010 & 28.07 & 28.07 & 51 & 13 August & 12 September & 45 & 504 \\
\hline 2011 & 18.07 & 12.07 & 88 & 8 August & 28 August & 42 & 832 \\
\hline
\end{tabular}

SPI seasonal pollen index

pollen season. The average length of the meteorological vegetation season in Wrocław in the analyzed period from 2002 to 2011 was 235 days, which correlates to the value of 234 days that is quoted in the literature (Dubicka 1996). The shortest vegetation season was observed in 2003 (207 days), while the longest vegetation seasons were observed in 2007, 2009 and 2010 (250 and 251 days). The vegetation seasons in the given decade usually began in the third part of March. Meanwhile, the ending date exhibited a greater variability (from the second half of October to the beginning of December) (Table 2).

In the case of adequate humidity resources, the energy resources are the deciding factor in plant development. In the analyzed 2002-2011 period, the sum of active temperatures in the vegetation season for the threshold temperature $5{ }^{\circ} \mathrm{C}$ (plant development processes) amounted to $3,333.8^{\circ} \mathrm{C}$; for $10{ }^{\circ} \mathrm{C}$ (active growth), 2,978.0 ${ }^{\circ} \mathrm{C}$; and for $15{ }^{\circ} \mathrm{C}$ (ripening), $1,850.3{ }^{\circ} \mathrm{C}$. The sum of active temperatures in the vegetation season for the physiological threshold of $5{ }^{\circ} \mathrm{C}$ was the lowest in 2003, whereas it was the highest in 2007, which is connected, above all, with the length of these seasons. The analysis of thermal resources in the first half of the year shows that the years 2002 and 2007, with values exceeding $1,000{ }^{\circ} \mathrm{C}$, and the year $2011\left(983{ }^{\circ} \mathrm{C}\right)$ were thermally privileged. The vegetation season in the year 2002 began late; yet, it was preceded by a warm prevernal season that began in the second half of January, with an average temperature above $3.6{ }^{\circ} \mathrm{C}$. Meteorological and aerobiological analyses show that 2007 was also an atypical year, due to large thermal resources in the beginning of the vegetation season, in addition to intense precipitation in July, which delayed the beginning of the pollen season. This is also confirmed by values of Selyaninov's hydrothermal index (Table 2).

The sum of active temperatures in the vegetation season for a threshold temperature of $5{ }^{\circ} \mathrm{C}$, which determines the onset of development processes in plants, had a minimum value in $2003\left(3,219^{\circ} \mathrm{C}\right)$ and a maximum value in $2007\left(3,426^{\circ} \mathrm{C}\right)$.
The sum of GDDs in the entire growing season was contained in the $2,169-2,446{ }^{\circ} \mathrm{C}$ interval. The sum of CHUs in the vegetation season had an average value of $3,765{ }^{\circ} \mathrm{C}$, while in the period from the beginning of the vegetation season to the day before the determined beginning of the pollen season of Artemisia, the average value of CHUs was $1,825^{\circ} \mathrm{C}$. With respect to this value, the years 2002 and 2005, when the Artemisia pollen season began at lower CHUs values, and the years 2007 and 2010, when the beginning of the season was connected with the highest CHUs values, which may be tied to other, non-biological, factors that shape the release and dispersion of pollen, were exceptional.

It should be noted that the statistically significant increasing trend in heat accumulations has been detected since 1971 in Wrocław. The sum of CHUs (calculated from March to June) has increased by about $100^{\circ} \mathrm{C}$ per decade. For example, the average accumulated heat units for the period 1971-1980 were calculated to be $1,014.4{ }^{\circ} \mathrm{C}$ and reached $1,318.8^{\circ} \mathrm{C}$ in 2001-2010. An increasing trend in heat accumulations can be either negative or positive impact on plant production (Bootsma et al. 2005).

The values of Selyaninov's hydrothermal index show that optimal hydrothermal conditions $(1.3<\mathrm{HTI}<1.6)$ in vegetation seasons before the start of pollen season occurred in the years 2004, 2005, 2008 and 2011, while the analyzed time periods in the years 2007, 2009 and 2010 are considered to be humid (Stachowski 2010; Wilczewski et al. 2012) (Table 2).

3.3 The impact of meteorological factors on the pollen season

The basic aim of the conducted analyses of the impact of meteorological conditions was the possibility of constructing forecasts for individual season stages (Orlandi et al. 2010; Voukantsis et al. 2010; Grewling et al. 2012), in particular, the beginning and end of the pollen season, the date of maximum daily pollen concentration and the SPI. The undertaken 
NOAA HYSPLIT MODEL

Backward trajectories ending at 0000 UTC 27 Jun 02 CDC1 Meteorological Data
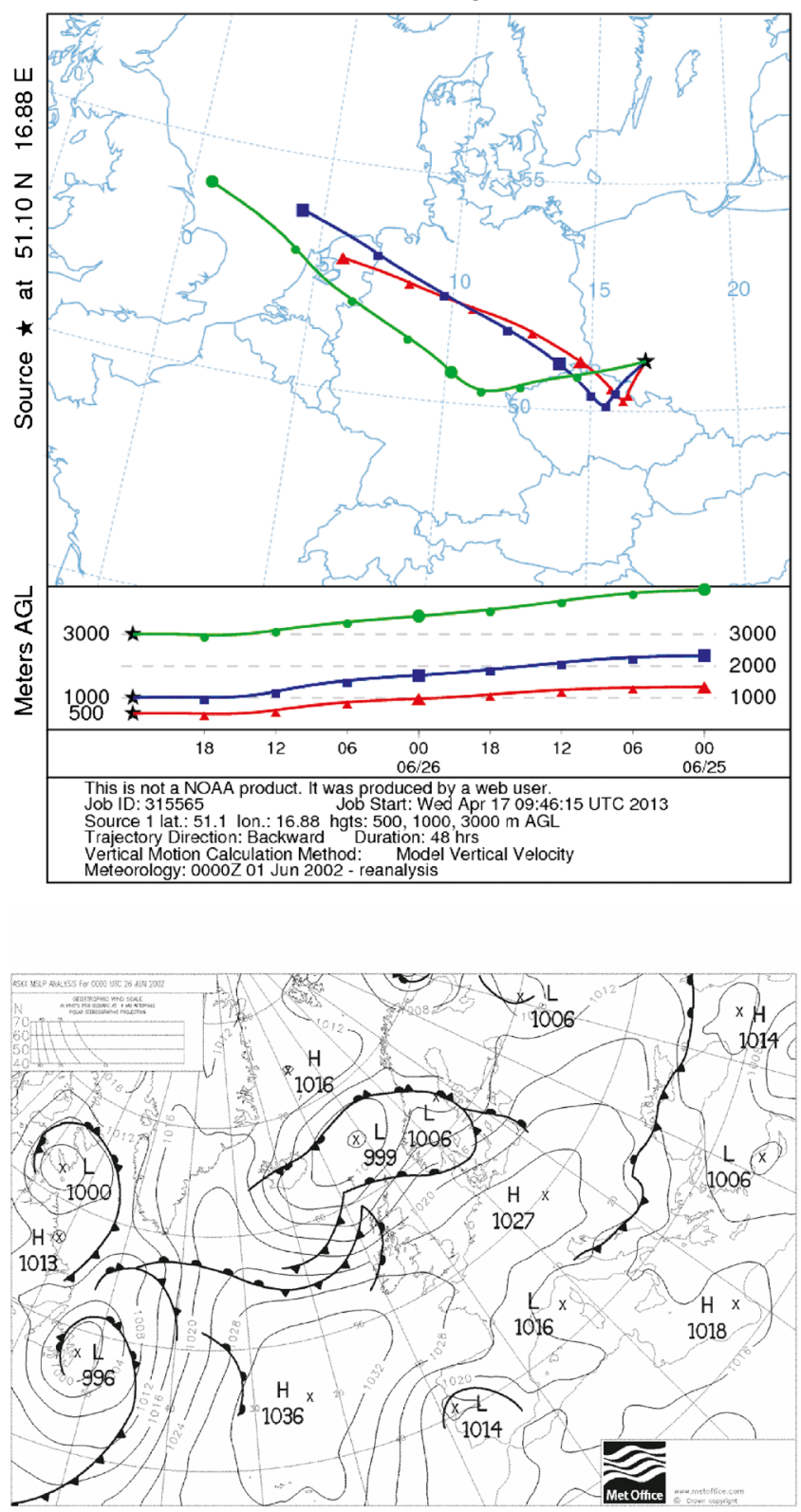

NOAA HYSPLIT MODEL

Backward trajectories ending at 0000 UTC 19 Jul 08 GDAS Meteorological Data

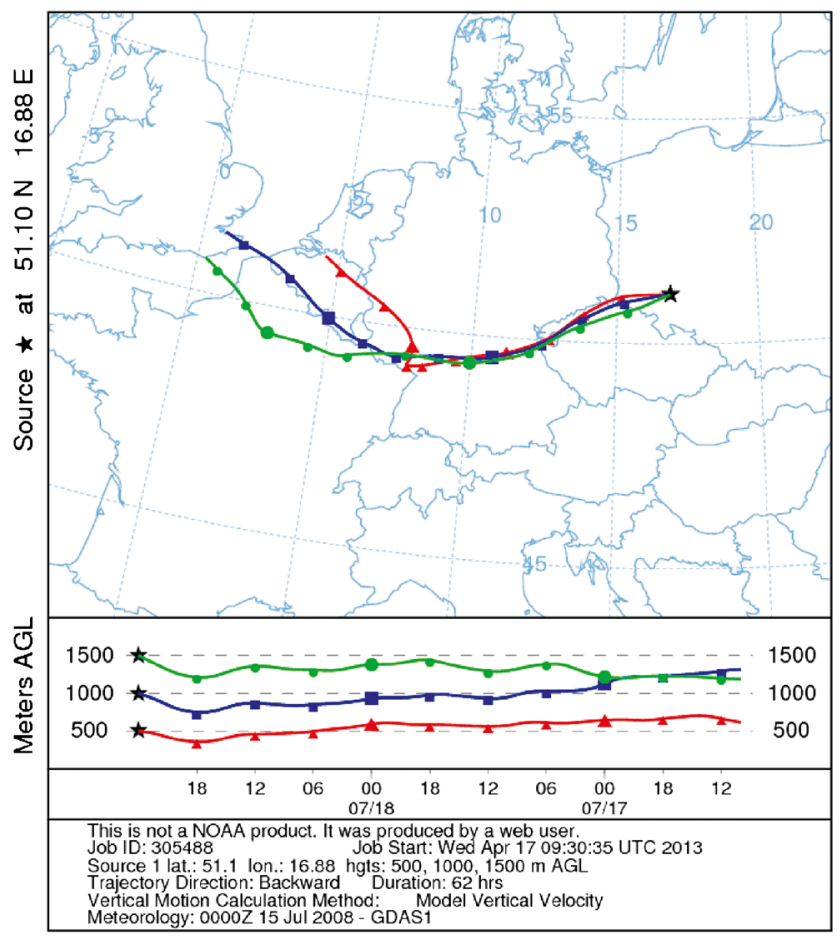

Fig. 2 The examples of back trajectory analysis during selected situation indicating the probable long-distance transport of Artemisia pollen grains (upper) and synoptic situation (lower) (source:www.wetterzentrale.de)

correlation analysis indicates that thermal and humidity resources are the most significant in shaping the main features of the pollen season.

In order to evaluate the impact of meteorological conditions on the beginning date of the Artemisia pollen season, raw meteorological data gathered from March until the beginning of July were used, which were then processed. Literature indicates that temperature and agroclimatic indices are helpful in forecasting the individual pollen season stages (GarcíaMozo et al. 2000). The mathematical models that were formed are mostly based on regression analysis (Galán et al. 2004;

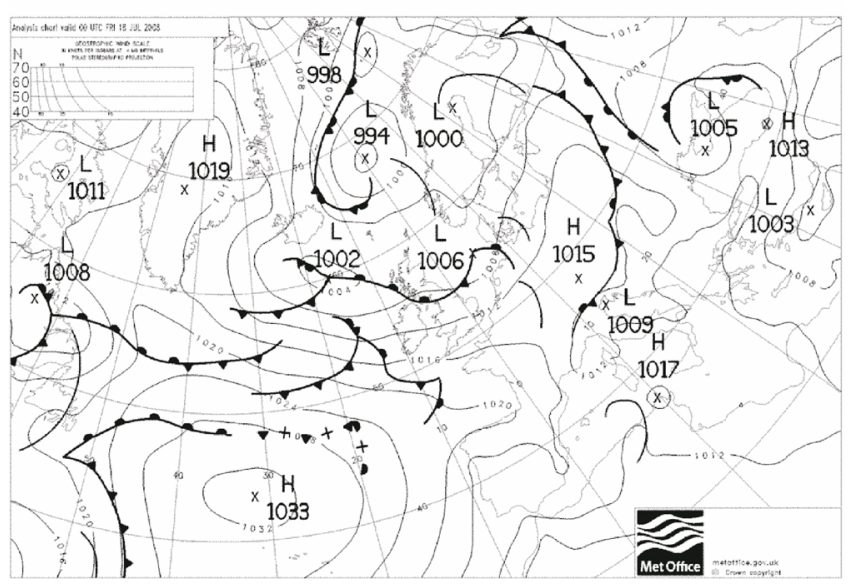

Stach et al. 2008), while cross-validation analysis may also be used to evaluate agrometeorological variables (Melaas et al. 2013).

The relationship between the start date of the Artemisia pollen season and basic thermal and moisture indicators that were determined for periods of various lengths preceding the start of the pollen season and for various thermal intervals was analyzed (Table 3). Among the analyzed indicators, the highest correlation coefficients were observed between the start date of the pollen season (START95) and CHUs and PTU, taking into account both the minimum and maximum 
Fig. 3 Dynamics of the Artemisia pollen seasons 20022011; stages of the pollen season: $A-1.0-2.5 \%, B-2.5-25.0 \%$, $C-25.0-50.0 \%, D-50.0 \%$, E-50.0-75.0\%, F-75.0$97.5 \%$ and $G-97.5-99.0 \%$ of the total annual pollen count. SPI seasonal pollen index. The date of maximum concentration is highlighted

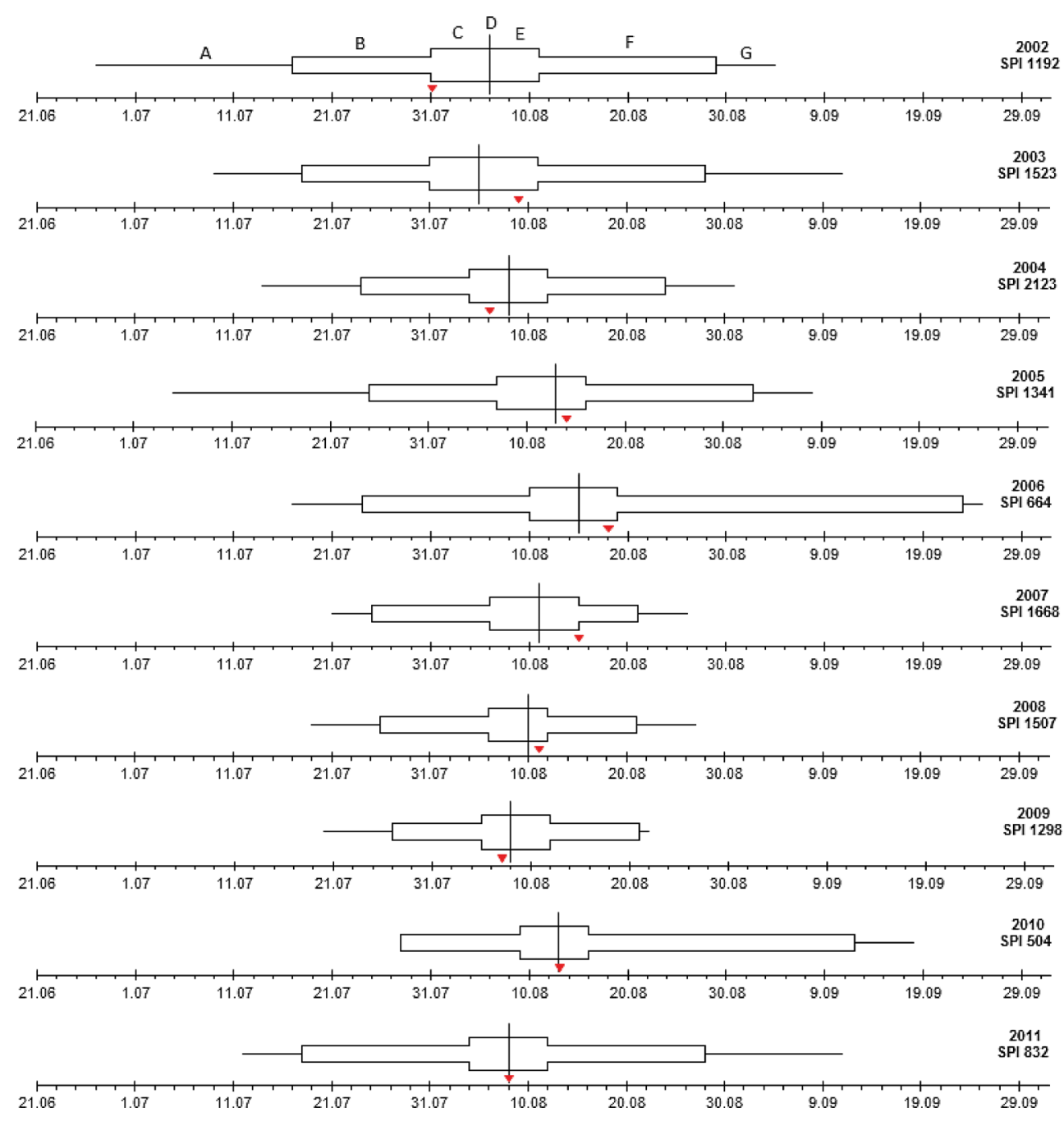

Table 2 Meteorological characteristic of vegetation season in Wrocław during the 2002-2011 time period

\begin{tabular}{|c|c|c|c|c|c|c|c|c|c|c|c|c|c|c|c|}
\hline \multirow[t]{2}{*}{ Description } & & \multicolumn{14}{|l|}{ Year } \\
\hline & & 2002 & 2003 & 2004 & 2005 & 2006 & 2007 & 2008 & 2009 & 2010 & 2011 & Avg & Min & Max & STD \\
\hline \multicolumn{2}{|l|}{ Start date } & 29.03 & 24.03 & 14.03 & 23.03 & 26.03 & 28.02 & 28.03 & 27.03 & 18.03 & 10.03 & 20.03 & 28.02 & 29.03 & 9 \\
\hline \multicolumn{2}{|l|}{ End date } & 2.11 & 16.10 & 9.11 & 12.11 & 1.11 & 4.11 & 16.11 & 1.12 & 23.11 & 9.11 & 09.11 & 16.10 & 01.12 & 13 \\
\hline \multicolumn{2}{|l|}{ Length (days) } & 219 & 207 & 241 & 235 & 221 & 250 & 234 & 250 & 251 & 245 & 235 & 207 & 251 & 15.2 \\
\hline \multirow{4}{*}{$\begin{array}{l}\text { Within the whole vegetation } \\
\text { season }\end{array}$} & $\sum \mathrm{T}\left(T_{\mathrm{d}}=5^{\circ} \mathrm{C}\right)$ & 3,271 & 3,219 & 3,311 & 3,262 & 3,406 & 3,426 & 3,292 & 3,385 & 3,350 & 3,417 & 3,334 & 3,219 & 3,426 & 73 \\
\hline & $\sum \mathrm{T}\left(T_{\mathrm{d}}=10^{\circ} \mathrm{C}\right)$ & 2,991 & 3,026 & 2,953 & 2,851 & 3,201 & 2,977 & 2,854 & 3,073 & 2,765 & 3,090 & 2,978 & 2,765 & 3,201 & 130 \\
\hline & $\sum \mathrm{CHUs}$ & 3,849 & 3,793 & 3,811 & 3,768 & 3,934 & 3,881 & 3,566 & 3,697 & 3,525 & 3,824 & 3,765 & 3,525 & 3,934 & 132 \\
\hline & $\begin{array}{c}\sum \operatorname{GDD}\left(T_{\text {base }}=\right. \\
\left.5^{\circ} \mathrm{C}\right)\end{array}$ & 2,400 & 2,358 & 2,314 & 2,278 & 2,446 & 2,364 & 2,194 & 2,240 & 2,169 & 2,299 & 2,306 & 2,169 & 2,446 & 89 \\
\hline \multirow[t]{3}{*}{ Before pollen season $^{a}$} & $\Sigma \mathrm{CHUs}$ & 1,546 & 1,819 & 1,751 & 1,525 & 1,876 & 2,229 & 1,753 & 1,898 & 2,043 & 1,814 & 1,825 & 1,525 & 2,229 & 210 \\
\hline & HTI & 1.0 & 1.0 & 1.4 & 1.6 & 0.9 & 1.7 & 1.5 & 2.1 & 1.8 & 1.5 & 1.4 & 0.9 & 2.1 & 0.4 \\
\hline & $\sum \mathrm{R}$ & 117 & 148 & 191 & 186 & 143 & 289 & 207 & 332 & 302 & 219 & 213 & 117 & 332 & 73 \\
\hline
\end{tabular}

Avg average value, Min minimum value, $\operatorname{Max}$ maximum value, $S T D$ standard deviation, $\sum T_{\left(T d=5^{\circ} \mathrm{C}\right)}$ temperature sum above threshold value $=5^{\circ} \mathrm{C}\left({ }^{\circ} \mathrm{C}\right)$, $\sum T_{\left(T d=10^{\circ} \mathrm{C}\right)}$ temperature sum above threshold value $=10^{\circ} \mathrm{C}\left({ }^{\circ} \mathrm{C}\right), \sum C H U s$ sum of crop heat units $\left({ }^{\circ} \mathrm{C}\right), \sum G D D_{\left(\text {Tbase }=5^{\circ} \mathrm{C}\right)}$ sum of growing degree day index above threshold value $=5^{\circ} \mathrm{C}, H T I$ hydrothermal index, $\sum R$ sum of precipitation $(\mathrm{mm})$

${ }^{a}$ Data calculated for the period from 1 st day of growing season to one day before beginning pollen one 
Table 3 Pearson correlation coefficients between start date (START95), end date (END95) of Artemisia pollen season, date of maximum daily concentration (MAX) and meteorological variables

\section{START95}

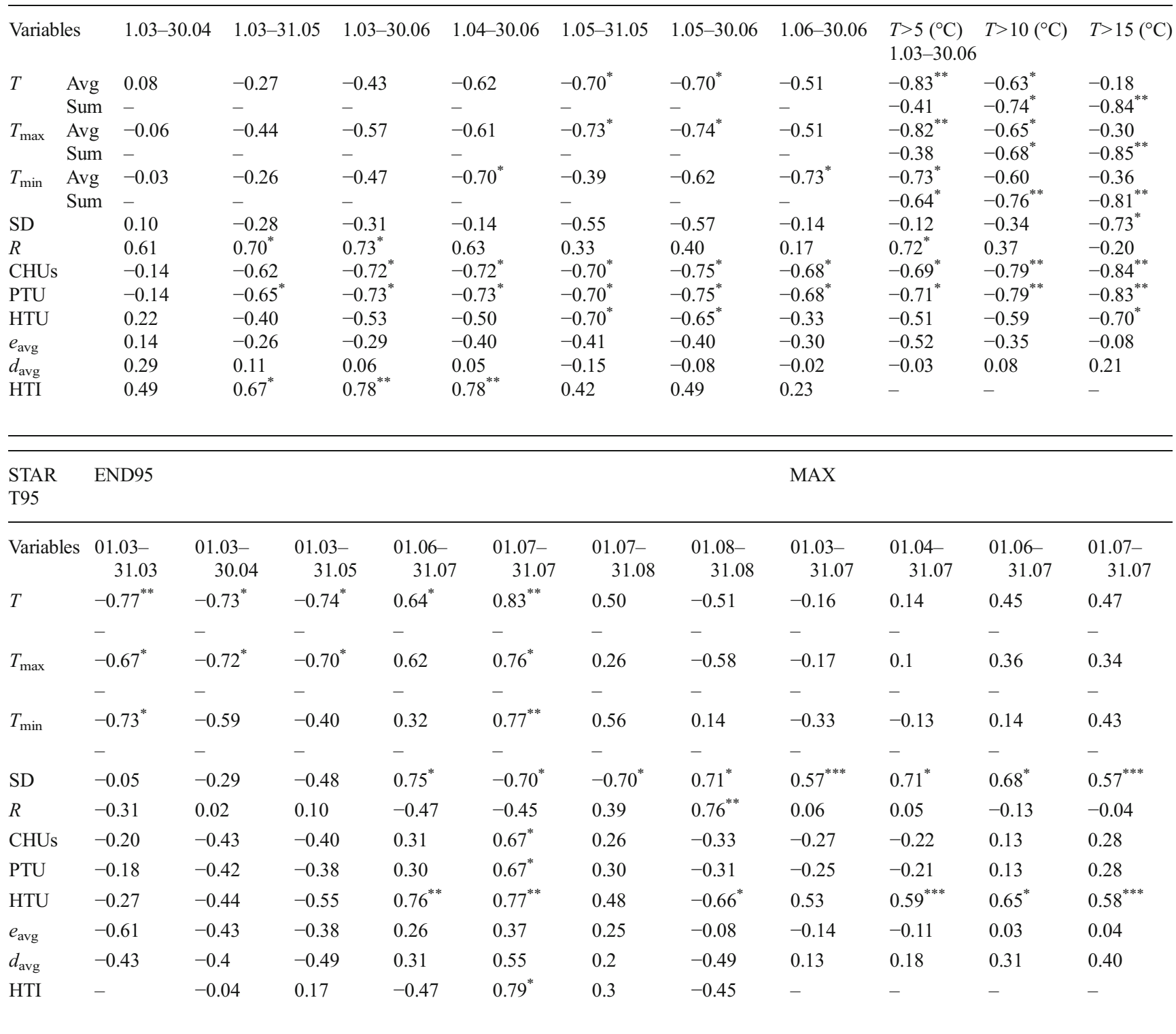

Avg average value, $T_{\max }$ maximum temperature $\left({ }^{\circ} \mathrm{C}\right), T_{\min }$ minimum temperature $\left({ }^{\circ} \mathrm{C}\right), S D$ sunshine duration $(\mathrm{h}), R$ precipitation $(\mathrm{mm}), C H U s$ crop heat units $\left({ }^{\circ} \mathrm{C}\right), P T U$ photothermal unit, $H T U$ heliothermal unit, $e_{a v g}$ average vapour pressure $(\mathrm{hPa}), d_{\text {avg }}$ average vapour pressure deficit $(\mathrm{hPa}), H T I$ hydrothermal index

${ }^{*}$ Correlation coefficient is significant at 0.05 level; ${ }^{* *}$ at 0.01 level; ${ }^{* * *}$ at 0.1 level (only for MAX)

temperature, with the PTU additionally taking the length of day into account. A somewhat weaker relationship for the same time periods was obtained for the mean daily maximum and minimum temperature, both for average and sum values. These relationships are strong $(r>|0.6|)$ and statistically significant for various periods of data generalization, both for the period of March to June and for shorter periods. The largest correlation coefficient was found between START95 and $T_{\max }$ and CHUs calculated for the 1.03 to 30.06 time period, with the thermal resources being summed only for days where the average daily temperature exceeded $15{ }^{\circ} \mathrm{C}$. Analysis of the monthly sums of CHUs index and temperature indicates that the variability in the pollen season start date is primarily determined by energy resources in May ( $r$ from -0.39 to -0.73 ) and June ( $r$ from -0.51 to -0.73 ). High correlation coefficients also occurred between the pollen season start date and Selyaninov's hydrothermal index $(r=0.78)$, showing the importance of springtime moisture resources (March/April-June). The meteorological 
Fig. 4 The examples of scatterplots and regression equation representing the relationship between the phases in pollen season and some meteorological variables. a Starting date of pollen season

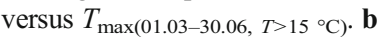
Starting date of pollen season versus $\mathrm{CHUs}_{(01.03-30.06)}$. $\mathrm{c}$ End date of pollen season versus

$\mathrm{SD}_{(01.06-31.07)}$. d End date of pollen season versus $\mathrm{HTI}_{(01-}$ 15.07). e Date of maximum daily pollen concentration versus $\mathrm{HTU}_{(01.06-31.07)}$. $\mathbf{f}$ Date of maximum daily pollen concentration versus $T_{\min (01-}$ 31.07). $\mathrm{g}$ SPI versus $T_{\max (01-15.07) \text {. }}$ h SPI versus $R_{(01-31.08)}$ a

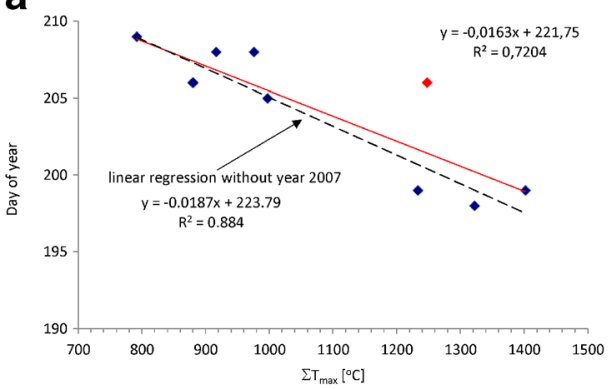

C

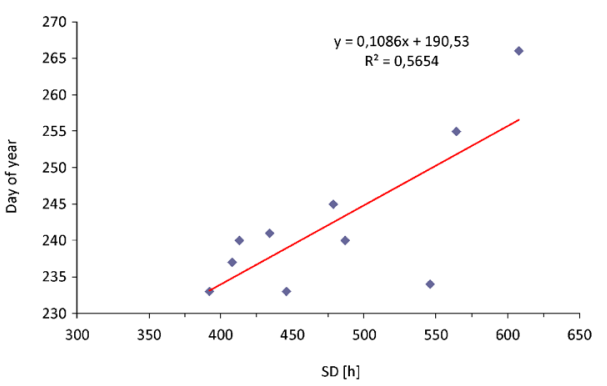

e
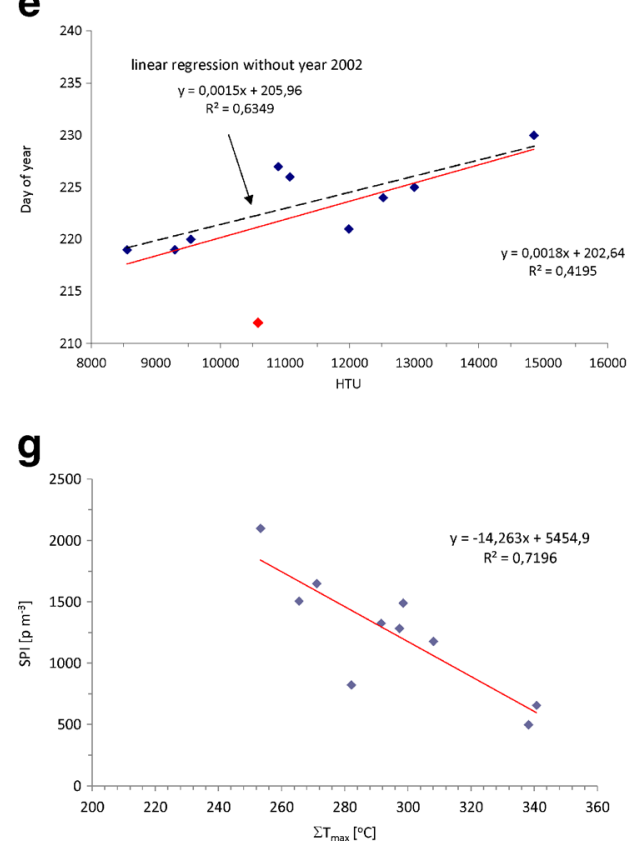

b

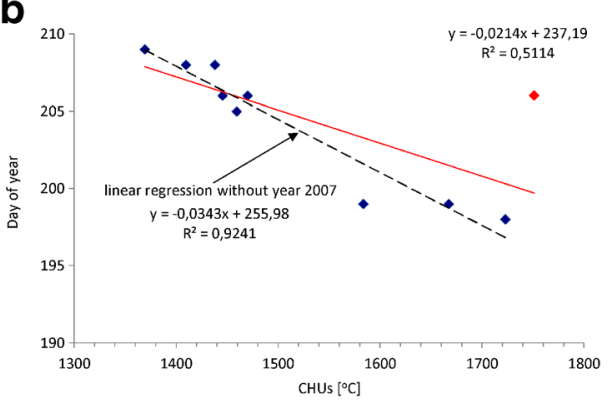

d

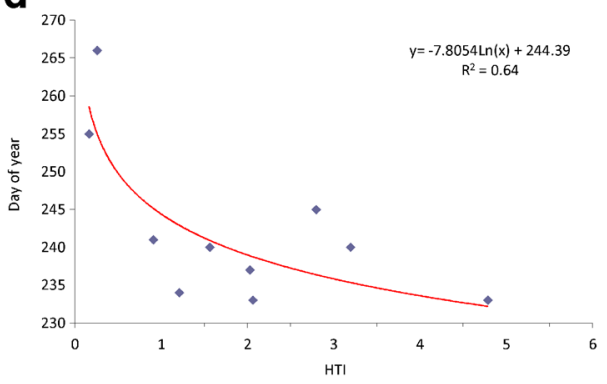

f

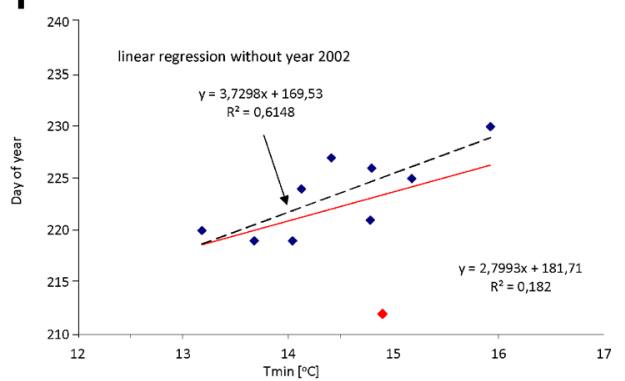

h

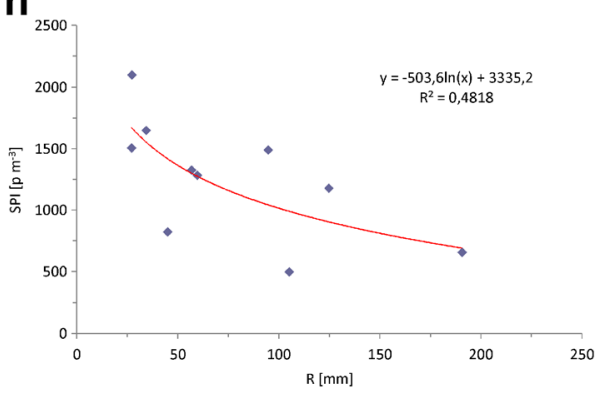

conditions that took place immediately before the Artemisia pollen season did not significantly and unambiguously influence the date of pollen season start. However, in some cases, such as the year 2007, they caused the delaying of this date; yet, this relationship was not found to be statistically significant.

Despite the generally high values of correlation coefficients, a specific analysis of these relationships shows that eliminating individual outlying data points significantly influence the strength of the dependence. An example of this is an analysis of the dependency between the pollen season start date and the cumulative value of the CHUs index from March until the beginning of June. The correlation coefficient between these two variables based on the data 10 years ago was -0.72 ; yet, if we exclude the outlying data, that is the year 2007, the value of the correlation coefficient increases to $r=-0.96$ (Fig. 4). In the case of this year, apart from energy resources, rainfall occurring just before the beginning of the Artemisia pollen season had a significant influence (Malkiewicz et al. 2013).

The length of the Artemisia pollen season in Wrockaw in the years 2002-2011 ranged from 26 up to 62 days, and the pollen season usually ended between late August and early September, with an average difference in the end date being about 10 days. 
Table 4 Pearson correlation coefficients between seasonal pollen index (SPI) and meteorological variables

\begin{tabular}{|c|c|c|c|c|c|c|c|c|c|c|c|c|c|}
\hline & Period & & & & & & & & & & & & \\
\hline $\begin{array}{l}T \\
\text { Avg }\end{array}$ & 0.46 & 0.32 & -0.03 & -0.37 & -0.21 & 0.05 & -0.16 & -0.50 & -0.33 & $-0.85^{* *}$ & -0.59 & -0.40 & 0.30 \\
\hline $\begin{array}{l}T_{\max } \\
\text { Avg }\end{array}$ & 0.31 & 0.25 & 0.06 & -0.13 & 0.13 & 0.14 & 0.10 & -0.36 & -0.04 & $-0.77 * *$ & -0.43 & -0.01 & 0.48 \\
\hline $\begin{array}{l}T_{\min } \\
\text { Avg }\end{array}$ & 0.61 & 0.49 & 0.28 & -0.02 & 0.00 & 0.17 & 0.02 & -0.07 & -0.02 & -0.62 & -0.45 & -0.24 & 0.05 \\
\hline SD & -0.28 & -0.16 & -0.51 & -0.44 & -0.23 & -0.12 & -0.31 & -0.52 & -0.46 & $-0.79 * *$ & -0.45 & -0.28 & 0.31 \\
\hline$R$ & 0.20 & -0.12 & -0.16 & -0.21 & $-0.68 *$ & -0.18 & -0.60 & -0.01 & -0.54 & 0.45 & -0.02 & $-0.78 * *$ & $-0.65^{*}$ \\
\hline CHUs & 0.20 & 0.17 & 0.17 & 0.13 & 0.19 & 0.23 & 0.17 & -0.03 & 0.12 & $-0.67 *$ & -0.33 & -0.01 & 0.32 \\
\hline PTU & 0.18 & 0.15 & 0.15 & 0.12 & 0.18 & 0.22 & 0.16 & -0.03 & 0.11 & $-0.67^{*}$ & -0.34 & -0.05 & 0.3 \\
\hline HTU & 0.05 & 0.02 & -0.43 & -0.44 & -0.26 & -0.05 & -0.27 & -0.49 & -0.41 & $-0.81 * *$ & -0.47 & -0.39 & 0.32 \\
\hline$e_{\mathrm{avg}}$ & 0.55 & 0.28 & -0.02 & -0.13 & -0.16 & 0.01 & -0.13 & -0.18 & -0.22 & -0.50 & -0.25 & -0.31 & -0.12 \\
\hline$d_{\text {avg }}$ & -0.11 & -0.20 & -0.46 & -0.48 & -0.38 & -0.21 & -0.38 & -0.53 & -0.43 & $-0.73^{*}$ & $-0.63^{*}$ & -0.48 & 0.12 \\
\hline HTI & & -0.03 & & & & -0.21 & & 0.00 & & 0.47 & $-0.65^{*}$ & $-0.72^{*}$ & -0.02 \\
\hline
\end{tabular}

Avg average value, $T_{\max }$ maximum temperature $\left({ }^{\circ} \mathrm{C}\right), T_{\min }$ minimum temperature $\left({ }^{\circ} \mathrm{C}\right), S D$ sunshine duration (h), $R$ precipitation $(\mathrm{mm}), C H U s$ crop heat units $\left({ }^{\circ} \mathrm{C}\right), P T U$ photothermal unit, $H T U$ heliothermal unit, $e_{\text {avg }}$ average vapour pressure $(\mathrm{hPa}), d_{\text {avg }}$ average vapour pressure deficit $(\mathrm{hPa}), H T I$ hydrothermal index

*Correlation coefficient is significant at the 0.05 level; ** at the 0.01 level

This indicated the importance of local factors (thermal resources and amount of days with precipitation) and not only of plant physiology. The dependence between the Artemisia pollen season end date and the climatic and agroclimatic indicators was found (Table 3, Fig. 4). This dependence is best described by Selyaninov's thermal index (calculated for the first 10 days of June) and the number of days with precipitation for July and August, air temperature, both maximum and minimum as well as average daily, in addition to sunshine duration, especially those recorded from June to August. However, the dependencies that were obtained were not as unambiguous, due to the large influence (and an increase in the correlation coefficient) of a year with a very long pollen season, which only ended on 23 September The results that were obtained indicate that warm and sunny weather in the first part of the Artemisia pollen season (July) contributed to the lengthening of the pollen season, along with an increased frequency of cloudy and rainy weather in August, which has a similar effect. An example of such an effect is the year 2006, where the total precipitation in August was as large as $190 \mathrm{~mm}$.

For forecasting allergy risk, it is important to be able to evaluate the occurrence of maximum daily concentrations during the pollen season. The maximum daily concentration date ranged from 31.07 to 18.08 , and in the majority of cases, it took place between 06.08 and 15.08. An analysis of correlation coefficients between the maximum daily concentration date and meteorological factors (Table 3 ) shows that these dependencies are weaker than those for the Artemisia pollen season start date or SPI. The correlation coefficients had the largest values for the sunshine duration, the heliothermal index and the air temperature for June and July (an almost proportional relationship). The correlation coefficients that were obtained taking into account the data from the beginning of the vegetation season show that a warm spring causes both earlier season start and an earlier maximum daily concentration date. However, it must be stressed that the results that were obtained were not statistically significant at a $p<0.05$

Table 5 Results of starting date regression models (START95)

\begin{tabular}{|c|c|c|c|c|c|}
\hline $\begin{array}{l}\text { START95 } \\
\text { Models }\end{array}$ & $\begin{array}{l}\text { Variables }(\mathrm{a}-\mathrm{f}) \text { and slope }(+ \text { or }-) \\
\text { of unstandardized coefficients }\end{array}$ & $R^{2}$ adj & STD & $\mathrm{F}$ & Sig. F \\
\hline M1 & $\mathrm{a}(+), \mathrm{c}(-)$ & 0.68 & 2.36 & 10.39 & 0.008 \\
\hline M2 & $\mathrm{a}(+), \mathrm{d}(-)$ & 0.64 & 2.48 & 9.02 & 0.012 \\
\hline M3 & $\mathrm{c}(-), \mathrm{e}(+)$ & 0.67 & 2.39 & 9.98 & 0.009 \\
\hline M4 & $\mathrm{b}(+), \mathrm{f}(-)$ & 0.69 & 2.30 & 11.14 & 0.007 \\
\hline M5 & $\mathrm{f}(-)$ & 0.66 & 2.40 & 18.83 & 0.002 \\
\hline
\end{tabular}

STD standard deviation, Sig significance 
Table 6 Results of SPI regression models

\begin{tabular}{|c|c|c|c|c|c|}
\hline $\begin{array}{l}\text { SPI } \\
\text { Models }\end{array}$ & $\begin{array}{l}\text { Variables (a-f) and slope }(+ \text { or }-) \\
\text { of unstandardized coefficients }\end{array}$ & $R^{2}$ adj & STD & $\mathrm{F}$ & Sig. F \\
\hline M1 & $\mathrm{a}(-), \mathrm{c}(-)$ & 0.83 & 201.44 & 22.63 & 0.001 \\
\hline M2 & $\mathrm{b}(-), \mathrm{c}(-)$ & 0.78 & 226.23 & 17.22 & 0.002 \\
\hline M3 & $\mathrm{a}(-), \mathrm{e}(-)$ & 0.78 & 225.63 & 17.33 & 0.002 \\
\hline M4 & $\mathrm{d}(-), \mathrm{a}(-)$ & 0.74 & 249.31 & 13.56 & 0.004 \\
\hline M5 & $\mathrm{f}(-), \mathrm{g}(+)$ & 0.74 & 248.80 & 13.63 & 0.004 \\
\hline
\end{tabular}

STD standard deviation, Sig significance

level for most cases. Such a significance level occurs only for sunshine duration and the heliothermal index (Fig. 4). No statistically significant relationships were found between the occurrence of rainfall during the pollen season and the date of maximum daily concentration. A year that stands out in terms of the maximum daily concentration date is 2002 , where the maximum daily concentration occurred very early, on the last day of July. This was a year with a long and warm prevernal season, which could have influenced plant development phases. Excluding this year from statistical analysis causes an increase in statistical significance; e.g. the determination coefficient $R^{2}$ between $\mathrm{HTU}_{(01.06-31.07)}$ and the maximum daily concentration date increases from 0.42 to 0.88 (Fig. 4), and the statistical significance of the correlation for other parameters ( $T, T_{\max }$, CHUs, PTU, and HTU) also increases.

An attempt was also made to estimate the influence of meteorological conditions on the recorded values of SPI (Table 4). A comprehensive analysis should take into account a number of factors that influence the course of the pollen season and the condition of the plants that produce pollen, including thermal and moisture resources during the phases of plant development, as well as temperature, occurrence of precipitation (Fig. 4) and atmosphere dynamics, which influence pollen release and the removal of pollen from air. Generally, the more compact and shorter the pollen season, the larger the values of SPI (correlation coefficient between SPI and the length of the pollen season $r=$

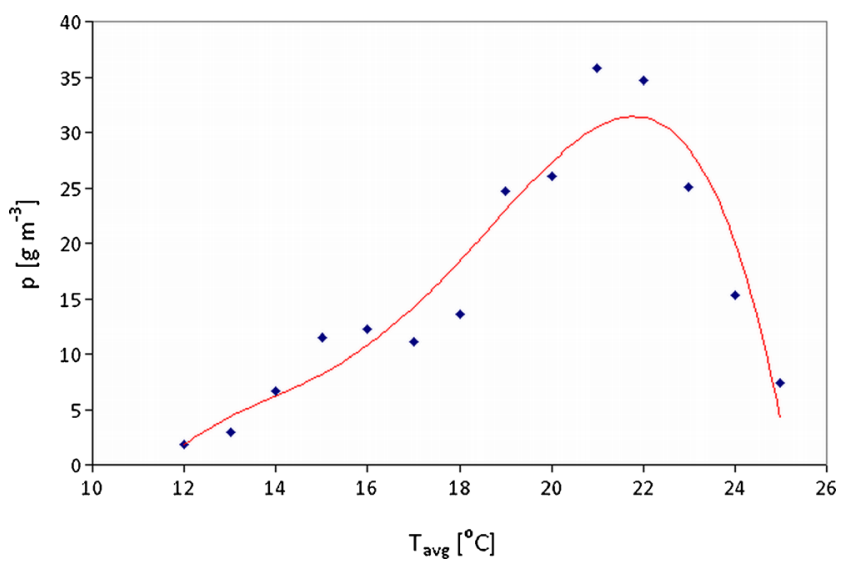

Fig. 5 The average concentration of Artemisia pollen as a function of mean daily temperature
-0.67). A strong relationship is also evident with the Artemisia pollen season end date. The earlier the pollen season ends, the higher the recorded values of SPI were $(r=-0.72)$. An analysis of the meteorological conditions shows that, above all, a relationship exists between the SPI and the temperature variable values ( $T, T_{\max }, T_{\min }$, CHUs, and HTU) that occur in July (Fig. 4) and in the beginning of spring.

The large influence of thermal variables on the pollen dispersal process, in particular, the pollen season start date and the SPI, shows the significance of the analysis that has been conducted in the context of climate change and constructing adaptation scenarios (Stach et al. 2007; Grewling et al. 2012).

\subsection{Forecasting of the pollen season start date and SPI}

Based on the correlation analysis, independent variables were chosen in order to create a regression model. The variables that were chosen had a correlation coefficient that was statistically significant at a minimum level of $p<0.05$. The regression analysis was performed for the entire data set (20022011). Among the models that were created, five each were chosen for the start date of the Artemisia pollen season, calculated using the $95 \%$ method, referred to as START95 models (Table 5) and for the SPI, referred to as SPI models (Table 6). The criteria for choosing the models were the lowest errors and the highest $\mathrm{F}$ coefficients that were obtained for a significance level of $p<0.05$. The variables that were included in the analysis were the following:

- For the pollen season start date (START95), total precipitation from March to May $\left(R_{01.03-31.05}\right)$ is designated as $a$; total precipitation from March to June $\left(R_{01.03-30.06}\right)$ as $b$; the sunshine duration sum from March to June, calculated for days where the average daily temperature $>15^{\circ} \mathrm{C}\left(\mathrm{SD}_{01.03-30.06, T \geq 15^{\circ} \mathrm{C}}\right)$ as $c$; the heliothermal index for the March-June period, calculated for days where the average daily temperature $>15{ }^{\circ} \mathrm{C}$ $\left(\right.$ HTUs $\left._{01.03-30.06,} T \geq 15{ }^{\circ} \mathrm{C}\right)$ as $d$; the hydrothermal index for the March-May period ( $\mathrm{HTI}_{01.03-31.05}$ ) as $e$; and total cumulative CHUs from March to June, 
Table 7 Cross-validation results for starting date regression models

\begin{tabular}{|c|c|c|c|c|c|c|c|c|c|c|}
\hline \multirow[t]{2}{*}{ No. } & \multicolumn{2}{|c|}{ Absolute differences } & \multirow[t]{2}{*}{$r$} & \multirow[t]{2}{*}{ ME } & \multirow[t]{2}{*}{ MPE } & \multirow[t]{2}{*}{ BIAS } & \multirow[t]{2}{*}{ RMSE } & \multirow[t]{2}{*}{ FB } & \multirow[t]{2}{*}{ FA2 } & \multirow[t]{2}{*}{ NMSE } \\
\hline & Max & Min & & & & & & & & \\
\hline M1 & 5.09 & 0.01 & $0.77 * *$ & -0.24 & -0.13 & 0.02 & 2.63 & 0.00 & 1.00 & 0.00 \\
\hline M2 & 5.77 & 0.04 & $0.73 *$ & -0.22 & -0.12 & 0.02 & 2.81 & 0.00 & 1.00 & 0.00 \\
\hline M3 & 5.31 & 0.62 & $0.75^{*}$ & -0.30 & -0.16 & 0.03 & 2.78 & 0.00 & 1.00 & 0.00 \\
\hline M4 & 5.66 & 0.02 & $0.78 * *$ & -0.06 & -0.04 & 0.01 & 2.52 & 0.00 & 1.00 & 0.00 \\
\hline M5 & 6.15 & 0.02 & $0.75^{*}$ & 0.01 & -0.01 & 0.00 & 2.64 & 0.00 & 1.00 & 0.00 \\
\hline
\end{tabular}

Max maximum differences, Min minimum differences, $r$ correlation coefficient, $M E$ mean error, MPE mean percentage error, BIAS a systematic deviation from the true value, RMSE root-mean-square error, FB fractional BIAS, FA2 factor of two, NMSE normalized mean square error

*Correlation coefficient is significant at the 0.05 level; ** at the 0.01 level

calculated for days where the average daily temperature $>15{ }^{\circ} \mathrm{C}\left(\mathrm{CHUs}_{01.03-30.06,} T \geq 15{ }^{\circ} \mathrm{C}\right)$ as $f$.

- For SPI, the hydrothermal index for the July-August period $\left(\mathrm{HTI}_{01.07-31.08}\right)$ is designated as $a$, total precipitation from April to August $\left(R_{01.04-31.08}\right)$ as $b$, sum of temperatures in the 10-20 July time period ( $\left.T_{\text {sum10.07-20.07 }}\right)$ as $c$, sum of sunshine duration in the period $01-15$ of July $\left(\mathrm{SD}_{01.07-15.07}\right)$ as $d$, the average vapour pressure deficit in the period 10-20 of July $\left(d_{10.07-20.07}\right)$ as $e$, the average temperature in the period $01-15$ of July $\left(T_{01.07-15.07}\right)$ as $f$, and the average minimal temperature for March $\left(T_{\min 01.03-31.03}\right)$ as $g$.

Regression models M1, M2, and M4 are assumed as variables in the precipitation total and a variable related to the energy resources in the environment, expressed as a sum of temperature (CHUs), the heliothermal index or the total of sunshine duration. Increasing the total precipitation before the beginning of the Artemisia pollen season caused it to be delayed, while higher temperatures and a higher sunshine duration accelerated its start. However, the number of days with an average daily temperature above $15^{\circ} \mathrm{C}$ has a greater impact. Model M3 takes into account sunshine duration and moisture resources as described by the hydrothermal index, while in Eq. (5), only CHUs were used.
Forecasting of SPI is a harder task, because the aggregate pollen concentration is strongly influenced by the total precipitation and the number of days with different rainfall intensities. Earlier studies have shown that there is no statistically significant correlation between the daily total precipitation and pollen concentration on that day and the following day. Therefore, it is not possible to unambiguously calculate the scavenging coefficients (Malkiewicz et al. 2013), and dependencies are statistically significant only for longer averaging periods. In constructing regression models, indicators were used that informed about moisture resources, i.e. the hydrothermal index, total precipitation and the vapour pressure deficit, in addition to energy resources, total/mean temperatures and sunshine duration. In the case of precipitation variables, totals that took into account August, i.e. the peak of the pollen season, were statistically significant and decreased the SPI. Also, an increase in the independent variables that describe energy resources caused a decrease in the SPI. Such a dependency is also confirmed by the average pollen concentration as it changes with the average daily temperature, the optimum thermal conditions occurring between 19 and $22^{\circ} \mathrm{C}$ (Fig. 5).

For the selected regression models, a leave-one-out crossvalidation was conducted, and then an error analysis was performed. The results that were obtained indicated a

Table 8 Cross-validation results for SPI regression models

\begin{tabular}{|c|c|c|c|c|c|c|c|c|c|c|}
\hline \multirow[t]{2}{*}{ No. } & \multicolumn{2}{|c|}{ Absolute differences } & \multirow[t]{2}{*}{$r$} & \multirow[t]{2}{*}{$\mathrm{ME}$} & \multirow[t]{2}{*}{ MPE } & \multirow[t]{2}{*}{ BIAS } & \multirow[t]{2}{*}{ RMSE } & \multirow[t]{2}{*}{ FB } & \multirow[t]{2}{*}{ FA2 } & \multirow[t]{2}{*}{ NMSE } \\
\hline & $\operatorname{Max}$ & Min & & & & & & & & \\
\hline M1 & 439.25 & 9.89 & $0.86^{* *}$ & -37.04 & -6.54 & 3.70 & 238.17 & -0.03 & 1.00 & 0.04 \\
\hline M2 & 477.54 & 9.01 & $0.86^{* *}$ & 0.83 & -2.26 & -0.08 & 233.15 & 0.00 & 1.00 & 0.03 \\
\hline M3 & 445.46 & 39.56 & $0.84 * *$ & -1.28 & -1.50 & 0.13 & 260.92 & 0.00 & 1.00 & 0.04 \\
\hline M4 & 729.19 & 63.38 & $0.67^{*}$ & -63.85 & -11.41 & 6.38 & 372.12 & -0.05 & 1.00 & 0.08 \\
\hline M5 & 618.47 & 56.86 & $0.78^{* *}$ & 8.31 & -3.53 & -0.83 & 297.86 & 0.01 & 1.00 & 0.06 \\
\hline
\end{tabular}

Max maximum differences, Min minimum differences, $r$ correlation coefficient, ME mean error, MPE mean percentage error, BIAS a systematic deviation from the true value, RMSE root-mean-square error, $F B$ fractional BIAS, FA2 factor of two, NMSE normalized mean square error

*Correlation coefficient is significant at the 0.05 level; ** at the 0.01 level 
possibility of using all the selected parameters for evaluating and predicting pollen seasons.

START95 models exhibit a fine fit, with minimal tendencies to overestimate, which is shown by BIAS, FB and NMSE being close to zero. In addition, other indicators show an agreement between the modelled and real values. The lowest mean error value expressed by ME, MPE and RMSE was obtained for the models M4, M5 and M1 (Table 7). In all the analyzed cases, the largest absolute error was obtained for the year 2007, showing the atypical conditions that year. The results that were obtained allow for constructing the forecasting models for predicting the start of the Artemisia pollen season.

In the case of SPI models (Table 8), despite the higher correlation coefficients between the measured and modelled values, an analysis of prediction error shows a somewhat worse model fit than in the case of START95. The FB indicator shows a lack of significant overestimates; yet, values of BIAS show that in the case of M1 and M4 models, there is an underestimation, and in the case of M2 and M5 models, there exists a small overestimation of the modelled values as compared with the measured values. The lowest mean error value as expressed by ME, MPE and RMSE indicated that of models M2, M3 and M1 exhibited the best fit. The small number of variables did not allow for the construction of models with a greater number of predictors, and therefore, an alternative in this case is the use of factor analysis or principal component analysis (PCA) in order to reduce the number of variables (Makra et al. 2004). A drawback of such analyses is the impossibility of conducting an in-depth evaluation of causality.

\section{Summary and conclusions}

The data presented in this paper represent the next step towards forecasting the Artemisia pollen season in Wrockaw, showing the relationship between different aspects of pollen appearance and specific meteorological variables.

Pollen monitoring conducted in Wrocław during 20022011 showed that Artemisia pollen could, in general, be described as compact of average length and with clear maximum concentration peaks.

The Artemisia pollen season dynamics were analyzed by designating seven consecutive stages which composed 1.0, 2.5, $25.0,50.0,75.0,97.5$ and $99.0 \%$ of the total annual sum. The pollen season start date ranged from 17 to 28 July and was influenced by the thermal resources (CHUs, $T_{\max }$, and temperature sums) in the period before the pollen season, especially in May and June. There were no statistically significant dependencies for meteorological factors that took place just before the beginning of the pollen season (first half of July). Another factor that strongly depends on meteorological conditions is SPI. SPI in the analyzed time period varied greatly from year to year, from 504 (2010) to 2,123 $\mathrm{p} \mathrm{m}^{-3}$ (2004). Total precipitation in July and
August and thermal factors just before the Artemisia pollen season had the greatest impact on this variable. However, it must be stressed that the longer the pollen season is, with a less prominent maximum, the lower the SPI values are. Much weaker dependencies exist between the date of maximum daily Artemisia pollen concentration or the end date of the pollen season and meteorological factors. The dependencies that were obtained allowed for a construction of regression models for the start date of the pollen season (START95) and SPI. We used a leave-one-out cross-validation analysis for determining the predictive accuracy of the models, and then an error analysis was conducted. None of the proposed models showed a tendency for a significant overestimation or underestimation of the estimated values. Forecasting the impact of thermal factors on the beginning of individual phenological phases is also significant in the context of climate change.

Open Access This article is distributed under the terms of the Creative Commons Attribution License which permits any use, distribution, and reproduction in any medium, provided the original author(s) and the source are credited.

\section{References}

Andersen TB (1991) A model to predict the beginning of the pollen season. Grana 30(1):269-275

Barney JN, DiTommaso A (2003) The biology of Canadian weeds. 118. Artemisia vulgaris L. Can J Plant Sci 83(1):205-215

Bellocchi G, Rivington M, Donatelli M, Matthews KB (2010) Validation of biophysical models: issues and methodologies. A review. Agron Sustain Dev 30:109-130

Bonofiglio T, Orlandi F, Ruga L, Romano B, Fornaciari M (2013) Climate change impact on the olive pollen season in Mediterranean areas of Italy: air quality in late spring from an allergenic point of view. Environ Monit Assess 185:877-890

Bootsma A, Gameda S, McKenney DW (2005) Potential impacts of climate change on corn, soybeans and barley yields in Atlantic Canada. Can J Soil Sci 85:345-357

Brown DM, Bootsma A (1993) Crop heat units for corn and other warmseason crops in Ontario. Ontario Ministry of Agriculture and Food Factsheet No. 93-119: Agdex 111/31, 4pp

D’Amato G, Spieksma FTM, Liccardi G, Jäger S, Russo M, Kontou-Fili K, Wuthrich B, Bonini S (1998) Pollen-related allergy in Europe. Allergy 53:567-578

de la Guardia CD, Alba F, de Linares C, Nieto-Lugilde D, Caballero JL (2006) Aerobiological and allergenic analysis of Cupressaceae pollen in Granada (Southern Spain). J Investig Allergol Clin Immunol 16(1):24-33

Dubicka M (1994) Wpływ cyrkulacji atmosfery na kształtowanie warunków klimatu (na przykładzie Wrocławia). Acta Universitatis Wratislaviensis 1591 Studia Geograficzne 60, pp 295

Dubicka M (1996) Termiczne pory roku we Wrocławiu. Acta Universitatis Wratislaviensis, 1974, Prace Instytutu Geograficznego, Seria C, Meteorologia i Klimatologia 3, pp 5-31

Dubicka M, Głowicki B (2000) Ekoklimat Karkonoszy w przekroju wieloletnim w świetle wskaźników kompleksowych. Opera Corcontica 37:55-61

Emberlin JC, Savage M, Woodman R (1993) Annual variations in the concentrations of Betula pollen in the London area, 1961-1990. Grana 32:359-363 
Galán C, Vázquez L, García-Mozo H, Domínguez E (2004) Forecasting olive (Olea europaea) crop yield based on pollen emission. Field Crop Res 86:43-51

Galán C, García-Mozo H, Vázquez L, Ruiz L, Diaz de la Guardia C, Domínguez-Vilches E (2008) Modeling olive crop yield in Andalusia, Spain. Agron J 100(1):98-104

García-Mozo H, Galan C, Gomez-Casero MT, Domingues-Vilches E (2000) A comparative study of different temperature accumulation methods for predicting the start of the Quercus pollen season in Córdoba (South West Spain). Grana 39:194-199

García-Mozo H, Galan C, Aira MJ, Belmonte J, Daz de la Guardia C, Fernandez D, Gutierrez AM, Rodriguez FJ, Trigo MM, DominguezVilches E (2002) Modelling start of oak pollen season in different climatic zones in Spain. Agric For Meteorol 110:247-257

Gidskehaug L, Anderssen E, Alsberg BK (2008) Cross model validation and optimisation of bilinear regression models. Chemometr Intell Lab 93:1-10

Giner MM, Carrión García JS, García Sellés J (1999) Aerobiology of Artemisia airborne pollen in Murcia (SE Spain) and its relationship with weather variables: annual and intradiurnal variations for three different species. Wind vectors as a tool in determining pollen origin. Int J Biometeorol 43:51-63

Goldberg C, Buch H, Moseholm I, Weeks ER (1988) Airborne pollen records in Denmark, 1977-1986. Grana 27:209-217

Grewling Ł, Šikoparija B, Skjøth CA, Radišić P, Apatini D, Magyar D, Páldy A, Yankova R, Sommer J, Kasprzyk I, Myszkowska D, Uruska A, Zimny M, Puc M, Jäger S, Smith M (2012) Variation in Artemisia pollen seasons in Central and Eastern Europe. Agric For Meteorol 160:48-59

Henderson JC, Weller SC (1985) Biology and control of Artemisia vulgaris. Proc. 40th North Central Weed Control Conf. 40:100-101

Hirst JM (1952) An automatic volumetric spore trap. Ann Appl Biol 39(2):257-265

Huculak W, Makowiec M (1977) Wyznaczanie meteorologicznego okresu wegetacyjnego na podstawie jednorocznych materiałów obserwacyjnych. Zeszyty Naukowe SGGW 25:65-72

Ipsen H, Formagren H, Lowenstein H, Ingermann L (1985) Immunochemical and biological characterization of mugwort (Artemisia vulgaris) pollen extract. Allergy 40:289-294

Kinney PL, Aggarwal M, Northridge ME, Janssen NAH, Shepard P (2000) Airborne concentrations of $\operatorname{PM}(2.5)$ and diesel exhaust particles on Harlem sidewalks: a community-based pilot study. Environ Health Perspect 108(3):213-218

Koivikko A, Kupias R, Makinen Y, Pohjola A (1986) Pollen seasons: forecasts of the most important allergenic plants in Finland. Allergy 41:233-242

Komorowski J (2012) Epidemiologia astmy w Polsce w oparciu o wyniki badania ECAP, Warszawa, pp 114

Latałowa M, Mietus M, Uruska A (2002) Seasonal variations in the atmospheric Betula pollen count in Gdańsk (southern Baltic coast) in relation to meteorological parameters. Aerobiologia 18:33-43

Laursen SC, Reiners WA, Kelly RD, Gero KG (2007) Pollen dispersal by Artemisia tridentata (Asteraceae). Int J Biometeorol 51:465-481

Makra L, Juhász M, Borsos E, Béczi R (2004) Meteorological variables connected with airborne ragweed pollen in Southern Hungary. Int $\mathrm{J}$ Biometeorol 49:37-47

Malkiewicz M, Klaczak K, Drzeniecka-Osiadacz A, Krynicka J, Migała K (2013) Types of Artemisia pollen season depending on the weather conditions in Wrocław (Poland), 2002-2011. Aerobiologia 30(1): 13-23. doi:10.1007/s10453-013-9304-4

Mandrioli P, Comtois P, Domininquez Vilches E, Galan Soldevilla C, Syzdek L, Isard S (1998) Sampling: principles and techniques. In: Mandrioli P, Comtois P, Levizzani V (eds) Methods in aerobiology. Pitagora Editrice, Bologna, Italy, pp 47-112

Melaas EK, Richardson AD, Friedl MA, Dragoni D, Gough CG, Herbst M, Montagnani L, Moors E (2013) Using FLUXNET data to improve models of springtime vegetation activity onset in forest ecosystems. Agric For Meteorol 171-172:46-56
Myszkowska D, Jenner B, Stępalska D, Czarnobilska E (2011) The pollen season dynamics and the relationship among some season parameters (start, end, annual total, season phases) in Kraków, Poland, 1991-2008. Aerobiologia 27:229-238

Nilsson S, Palmberg-Gotthard J (1982) Pollen calendar for Huddinge (Sweden), 1977-1981. Grana 21:183-185

OMAFRA (Ontario Ministry of Agriculture, Food and Rural Affairs) (2009) Agronomy guide for field crops. Publication 811, Toronto, Canada, pp 306

Orlandi F, Sgromo C, Bonofiglio T, Ruga L, Romano B, Fornaciari M (2010) Yield modelling in a Mediterranean species utilizing causeeffect relationships between temperature forcing and biological processes. Sci Hortic 123:412-417

Puc M (2006) Ragweed and mugwort pollen in Szczecin, Poland. Aerobiologia 22:67-78

Samborski AS, Bednarczuk J (2009) Termiczne pory roku w okolicach Zamościa w latach 2001-2008. Acta Agrophys 14(1):187-194

Selyaninov GT (1937) Methods of climate description to agricultural purposes. In: World climate and agriculture handbook, Leningrad, Moscow, pp 5-27

Spieksma FTM, von Wahl PG (1991) Allergenic significance of Artemisia (mugwort) pollen. In: Bonini S, D’Amato G, Spieksma FTM (eds) Allergenic pollen and pollinosis in Europe. Blackwell, Oxford, UK, pp 49-56

Spieksma FT, Charpin H, Nolard N, Stix E (1980) City spore concentrations in the European Economic Community (EEC). IV. Summer weed pollen (Rumex, Plantago, Chenopodiaceae, Artemisia), 1976 and 1977. Clin Allergy 10:319-329

Środowisko Wrocławia. Informator 2010 (2010) Lemitor Ochrona Środowiska, Wrocław, pp 213

Stach A, García-Mozo H, Prieto-Baena JC, Czarnecka-Operacz M, Jerenowicz D, Silny W, Galan C (2007) Prevalence of Artemisia species pollinosis in western Poland: impact of climate change on aerobiological trends, 1995-2004. J Investig Allergol Clin Immunol 17(1):39-47

Stach A, Smith M, Prieto Baena JC, Emberlin J (2008) Long-term and shortterm forecast models for Poaceae (grass) pollen in Poznań, Poland, constructed using regression analysis. Environ Exp Bot 62:323-332

Stachowski P (2010) Ocena suszy meteorologicznej na terenach pogórniczych w rejonie Konina. Ochrona Środowiska 12:587-606

Sydbom A, Blomberg A, Parnia S, Stenfors N, Sandström T, Dahlén SE (2001) Health effects of diesel exhaust emissions. Eur Respir J 17:733-746

Szyga-Pluta K (2011) Termiczne pory roku w Poznaniu w latach 20012008. Przegląd Geograficzny 83(1):109-119

Thavaprakaash N, Jagannathan R, Velayudham K, Gurusamy L (2007) Seasonal influence on phenology and accumulated heat units in relation to yield of baby corn. Int J Agric Res 2:826-831

Tombácz S, Makra L, Balint B, Motika G, Hirsch T (2007) The relation of meteorological elements and biological and chemical air pollutants to respiratory diseases. Acta Climatologica Chorologica 40-41:135-146

Tutin TG, Heywood VH, Burges NA, Valentine DH, Walters SM, Webb DA (1980) Flora Europaea. Cambridge University Press, Cambridge, UK, pp 178-186

Voukantsis D, Niska H, Karatzas K, Riga M, Damialis A, Vokou D (2010) Forecasting daily pollen concentrations using data-driven modeling methods in Thessaloniki, Greece. Atmos Environ 44:5101-5111

Weryszko-Chmielewska E, Piotrowska K (2004) Airborne pollen calendar of Lublin, Poland. Ann Agric Environ Med 11:91-97

Wilczewski E, Skinder Z, Szczepanek M (2012) Effect of weather conditions on yield of Tansy phacelia and common sunflower grown as stubble catch crop. Pol J Environ Stud 21(4):1053-1060

Wolf F, Puls KE, Bergmann CC (1998) A mathematical model for mugwort (Artemisia vulgaris L.) pollen forecasts. Aerobiologia 14:359-373

Żmudzka E (2012) Wieloletnie zmiany zasobów termicznych w okresie wegetacyjnym i aktywnego wzrostu roślin w Polsce. Woda Środowisko Obszary Wiejskie 12(2):377-389 